
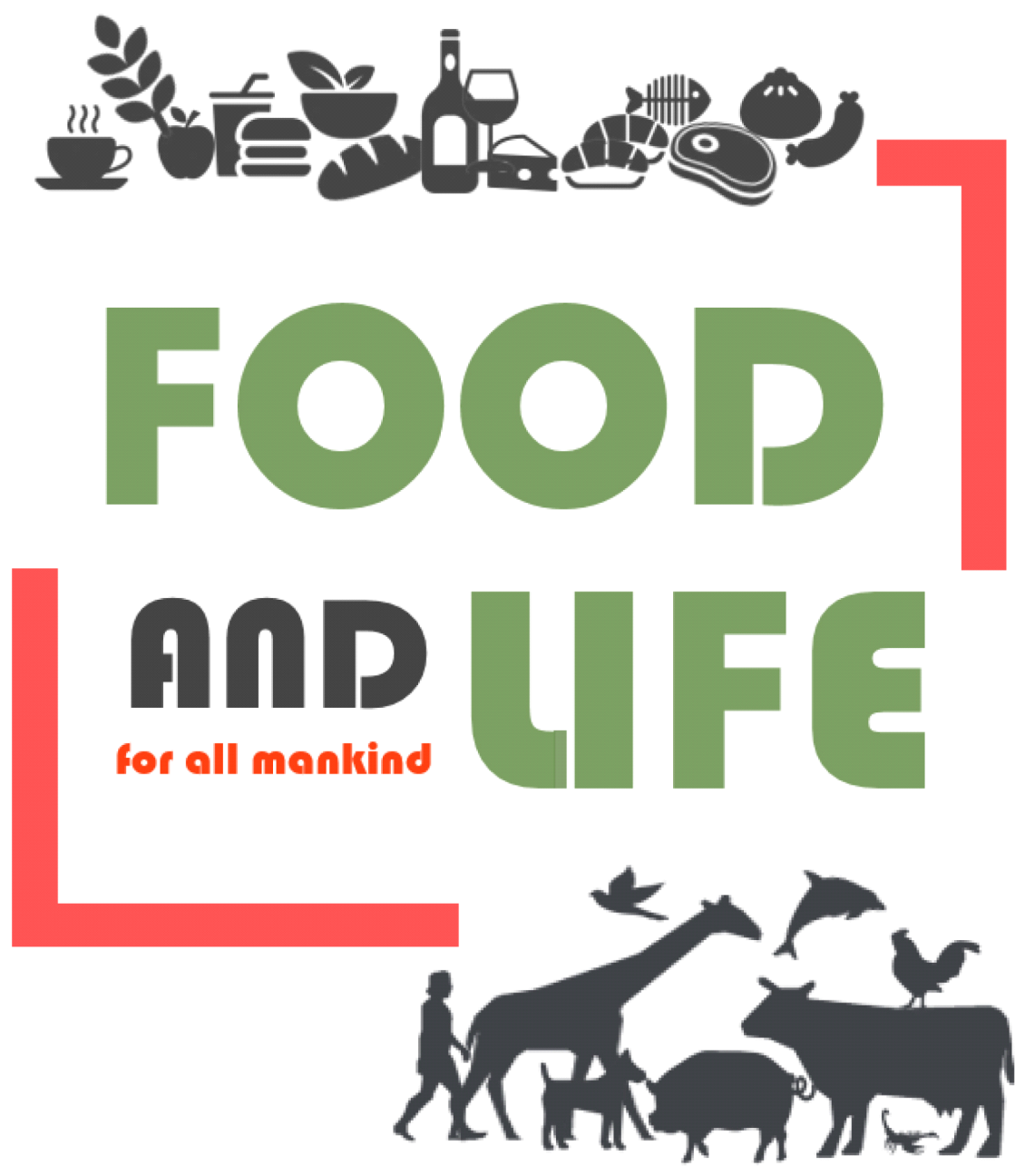

The Food and Life has published all type articles such as research articles, review articles, survey articles, research note, short communication or editorial since 2020. It covers the all scientific and technological aspects of food and life science.

\title{
https://www.foodnlife.org
}




\title{
숙성 및 가열에 따른 돼지고기의 육색과 잔존 아질산이온의 변화
}

\author{
강혜진 ${ }^{1}$, 이승연 ${ }^{1, *}$, 진상근 $^{2}$ \\ 1중앙대학교 동물생명공학과 \\ 2경남과학기술대학교 동물소재공학과
}

\section{Change of meat color and residual nitrite on pork with aging and heating}

\author{
Hea Jin Kang ${ }^{1}$, Seung Yun Lee,*, Sang Keun $\mathrm{Jin}^{2}$ \\ ${ }^{1}$ Department of Animal Science and Technology, Chung-Ang University, Anseong 17546, Korea \\ ${ }^{2}$ Department of Animal Resources Technology, Gyeongnam National University of Science and Technology, Jinju 52725, Korea
}

\begin{abstract}
This study aimed to determine the changes in meat color ( $L^{*}, a^{*}$, and $\left.b^{*}\right)$, residual nitric acid ion, myoglobin (Mb), and met-myoglobin contents in pork loin aged and heated with the addition of sodium nitrite. The meat color was measured by using a chromameter, and visual sensory evaluation was used to determine for redness and brightness. When the pork loin was aged with sodium nitrite, the redness $\left(\mathrm{a}^{*}\right)$, chroma $\left(\mathrm{C}^{*}\right)$ and hue angle $(\Delta \mathrm{H})$ values were higher, and the lightness $\left(L^{*}\right)$, yellowness $\left(b^{*}\right)$, and whiteness $\left(W^{*}\right)$ values were lower than those of pork loin aged without sodium nitrite. The residual nitric acid ion, myoglobin, and met-myoglobin contents were increased by the sodium nitrite treatment. Although the meat color of the heated pork loin with sodium nitrite was similar to that of the aged pork loin with sodium nitrite, the residual nitric acid ion content decreased. These results indicate that the addition of sodium nitrite to pork loin, which undergoes color fading during aging, can improve consumer preference through meat stabilization effects and reduce residual nitric acid ion formation caused by moderate heating.
\end{abstract}

Keywords: pork loin, nitrite, meat color, aging, heating

\section{서 론}

돼지고기 소비가 증가함에 따라 보존 기한 연장, 보수력 증 진, 항산화 작용, 미생물 억제 작용을 위하여 다양한 식품 첨가 제가 사용되고 있다(Han et al., 2012). 특히 아질산염(nitrite; $\mathrm{NaNO}_{2}$ )은 육제품의 발색을 고정시키고 풍미를 증진시키며, 산 패취를 감소시키는 등 품질에 중요한 영향을 미친다고 알려져 있으며, 이는 육제품에서 아스코르브산의 환원 작용을 통해 나 타난다(Cho et al., 2006; Jeong et al., 2010). 이뿐만 아니라 아 질산염은 Clostridium botulinum의 성장을 억제하고, 독소 및 포자 생성을 억제하여 육제품 섭취로 인한 식중독을 예방할 수 있다(Ha et al., 2015). 그러나 아질산염은 그 자체로도 독성을 가질 수 있을 뿐만 아니라, 과량 섭취 또는 산성 조건 하에서 $\mathrm{N}$-nitrosamine을 형성하여 암을 유발한다고 알려져 있다(Cho et al., 2006; Kim et al., 2014). 또한, 아질산염은 헤모글로빈의 2 가철을 3 가철로 산화시켜 met-hemoglobinemia를 유발하며
(Kim et al., 2014), 이는 산소 운반 능력을 저하시키고, 급성 청 색증 유발 가능성이 있다고 보고되고 있다(Kim and Choi, 2007). 이러한 유해성에 대한 논란이 있음에도 불구하고, 현재 까지 식중독균 예방과 발색제로서 아질산염을 대체 가능한 염 지제 및 발색제가 개발되지 않았다. 따라서 식품의약품안전처 (MFDS, 2020)에 따라 식품 내 잔류하는 아질산이온의 양을 70 $\mathrm{ppm}$ 이하로 제한하여 사용해야 한다.

식육의 색을 결정하는데 있어서 가장 큰 역할을 하는 마이오 글로빈(myoglobin)은 단백질인 글로빈(globin)과 철을 포함하 는 비단백질인 힘 고리(heme ring)로 구성되어 있다(Claus, 2007). 일반적으로 돼지고기는 구입 후 냉장 저장 및 가열조리 하여 섭취하게 되는데, 저장하는 동안 마이오글로빈 내 철이 산 소와 반응하여 선홍색인 옥시마이오글로빈(oxy-myoglobin)이 갈색인 메트마이글로빈(met-myoglobin)으로 변한다(Faustman et al., 2010). Greene 등(1971)에 따르면 육색은 소비자가 생육

\footnotetext{
"Corresponding author : Seung Yun Lee. Department of Animal Science and Technology, Chung-Ang University, Anseong 17546, Korea. Tel: +82-31-670-4673, E-mail: seungyun.lee57@gmail.com

This is an Open-Access article distributed under the terms of the Creative Commons Attribution Non-Commercial License which permits unrestricted non-commercial use, distribution, and reproduction in any medium, provided the original work is properly cited (http://creativecommons.org/licenses/by-nc/4.0/).
} 
을 구입하는데 가장 큰 요인 중 하나인데, 갈색 색소가 총 색소 의 $30 \%-40 \%$ 일 경우 선호도가 떨어진다고 보고하였고, 숙성 또 는 가공 시 아질산염의 첨가에 의하여 육색 보존 및 마이오글 로빈의 산화 방지 효과를 보인다고 알려져 있다(Park and Kim, 2009). 따라서 본 연구는 돼지고기 등심을 냉장 숙성 및 습열조 리하였을 때 아질산염의 첨가에 따라 육색과 품질에 어떠한 영 향을 미치는지 알아보고자 실시하였다.

\section{재료 및 방법}

\section{염지액 제조 및 원료의 처리}

시료는 태성축산유통에서 9두 $\mathrm{LYD}$ (랜드레이드, 요크셔 및 두록의 삼원교잡종) 암컷 돼지 좌 반도체의 제 5 번에서 제 6 번 갈비의 등심을 구입하였다. $4 \pm 1^{\circ} \mathrm{C}$ 냉장온도에서 1 일 보관한 후, 각 등심을 두께 약 $13 \mathrm{~cm}$, 중량 약 $650 \mathrm{~g}$ 으로 3등분하여 27 개 의 시료로 분할하였다. 무작위 분류된 시료는 3 번의 반복 실험 에 사용할 수 있도록 9분할씩 임의로 나누어 3 개의 처리구를 확보하였다. 아질산염 첨가 유무에 대한 육색 및 품질을 확인 하기 위하여 $\mathrm{C}(\mathrm{Control}), \mathrm{T}(\mathrm{NaCl}$ treatment), N(NPS treatment) 으로 처리구를 설정하였다(Fig. 1). 3분할로 이루어져 있는 각 처리구는 R(raw), A(aging), H(heating)로 표기한 후, 숙성 및 가열 여부에 따른 품질을 측정하였다. 염지액은 Table 1 과 같이 공통적으로 설탕, 인산염, 비타민 $\mathrm{C}$ 가 포함되었고, $\mathrm{NaCl}$ 을 첨 가한 처리구를 $\mathrm{T}$ 처리구로, nitrite pickle salt(NPS, NaCl: $\left.\mathrm{NaNO}_{2}=99: 1\right)$ 를 첨가한 처리구를 $\mathrm{N}$ 처리구로 하였다. 염지제 에 따라 분류된 등심을 숙성 및 가열하기 위하여 3 등분하였고, 아무 처리를 하지 않은 생고기 상태의 등심을 $\mathrm{R}$ 처리구로 표기 하였다. A 처리구는 제조한 세 가지 $(\mathrm{C}, \mathrm{T}, \mathrm{N})$ 염지액 $1 \mathrm{~L}$ 에 650 $\mathrm{g}$ 의 등심이 잠기도록 담구어 냉장 온도 $\left(5 \pm 1^{\circ} \mathrm{C}\right)$ 에서 2 일간 숙성

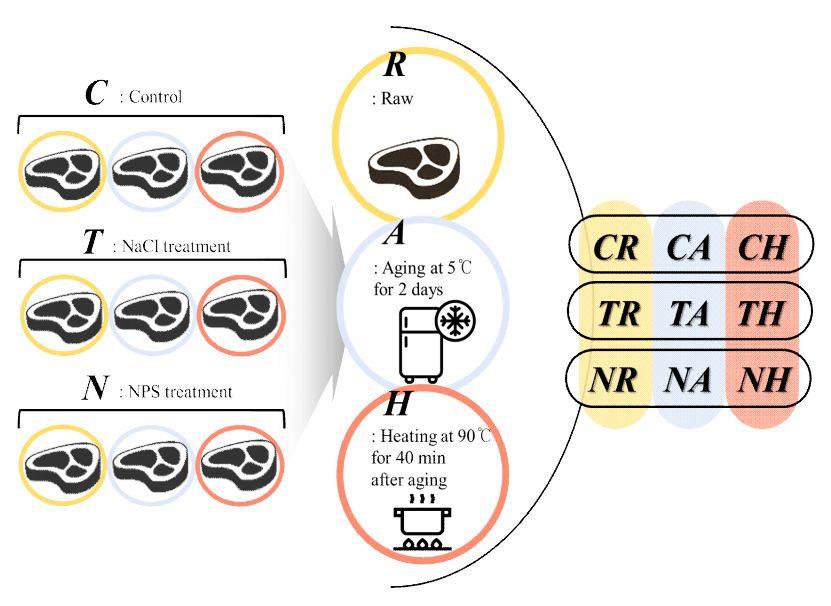

Fig. 1. Overview of pork treatment. (NPS, nitrite pickle salt, $\left.\mathrm{NaCl}: \mathrm{NaNO}_{2}=99: 1\right)$
Table 1. Formula of curing solution

\begin{tabular}{|c|c|c|c|}
\hline \multirow{2}{*}{ Ingredients } & \multicolumn{3}{|c|}{ Treatment (\%) } \\
\hline & C & $T$ & $N$ \\
\hline Sugar & 2.25 & 2.25 & 2.25 \\
\hline Phosphate & 1.1 & 1.1 & 1.1 \\
\hline Vitamin C & 0.28 & 0.28 & 0.28 \\
\hline Water & 96.37 & 90.81 & 90.81 \\
\hline $\mathrm{NaCl}$ & - & 5.56 & 5.50 \\
\hline $\mathrm{NaNO}_{2}$ & - & - & 0.06 \\
\hline Total & 100 & 100 & 100 \\
\hline
\end{tabular}

(aging)하였다. H 처리구는 A 처리구와 동일하게 염지 숙성을 진행하였고, 숙성이 종료된 후 진공포장하여 $90^{\circ} \mathrm{C}$ 에서 40 분간 가열(heating)한 후 육색 및 품질 측정을 위하여 진공포장을 제 거하여 사용하였다. 모든 처리구의 육색 측정 시 등심의 표면 과 자른 후 단면을 사용하였다.

\section{육색 측정}

육색 측정은 chroma meter(CR 400, Konica minolta, Tokyo, Japan)를 사용하여 명도(lightness)를 나타내는 L*, 적색도(redness)를 나타내는 $a^{*}$, 황색도(yellowness)를 나타내는 $b^{*}$ 를 측정 하였고, 이를 통해 백색도(whiteness)를 나타내는 $\mathrm{W}^{*}$ 를 $\mathrm{L}^{*}-3 \mathrm{~b}^{*}$

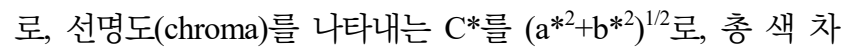
이(total color difference)를 나타내는 $\Delta \mathrm{E}^{*} \mathrm{ab}$ 를 $\mathrm{a} * \mathrm{~b}^{*}\left(\Delta \mathrm{L}^{* 2}+\Delta\right.$

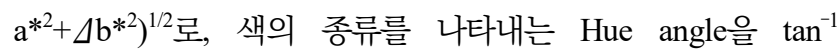
$\left(\mathrm{b}^{*} / \mathrm{a}^{*}\right)$ 로 계산하였다. 이때 $\mathrm{L}^{*}=89.2, \mathrm{a}^{*}=0.921, \mathrm{~b}^{*}=0.783$ 인 표 준색판을 사용하여 표준화한 후 모든 측정값을 5 회 반복하여 측정하였다.

\section{잔존 아질산이온(residual nitrite, $\mathrm{NO}_{2}$ ) 측정}

잔존 아질산이온(residual nitrite)의 측정은 식품공전(2002)의 디아조화법을 이용하여 분석하였다. $10 \mathrm{~g}$ 시료에 $90 \mathrm{~mL}$ 의 $80^{\circ} \mathrm{C}$ 증류수를 첨가하여 homogenizer(T25 Basic, IKA, Staufen, Germany)로 균질한 후 homogenizer(T25, Germany)를 $80^{\circ} \mathrm{C}$ 증 류수 $50 \mathrm{~mL}$ 로 세척하여 플라스크에 혼합하였다. $0.5 \mathrm{~N}$ sodium hydroxide와 $12 \%$ zinc sulfate를 각각 $10 \mathrm{~mL}$ 씩 넣고 혼합하여 $80^{\circ} \mathrm{C}$ water bath에서 20 분간 반응시킨 후 식힌 다음, acetic ammonium buffer solution $20 \mathrm{~mL}$ 를 넣고 혼합하였다. 혼합한 시료는 증류수로 최종 부피가 $200 \mathrm{~mL}$ 되도록 보정하고, 상온 에서 10 분간 방치한 후 여과지를 사용하여 여과하였다. 여과한 시료에 $2 \mathrm{~mL}$ 의 sulfanilamide, $0.1 \mathrm{~mL}$ 의 N-1-naphthylethylene diamine dihydrochloride 및 $0.2 \mathrm{~mL}$ 의 증류수를 혼합하여, 이를 20 분간 방치한 후 분광광도계(Uvikon 922, Kontron, Augsburg, 
Germany)로 $540 \mathrm{~nm}$ 파장에서 흡광도를 측정하였다. Blank와 표준물질은 시료 대신 증류수를 사용하여 동일한 방법으로 측 정하였다.

\section{마이오글로빈(Mb) 및 메트마이오글로빈(met-Mb) 측정}

마이오글로빈 및 메트마이오글로빈 함량을 측정하기 위하여 Chen(2002)의 방법을 참고하였다. $5 \mathrm{~g}$ 시료에 $10 \mathrm{~mL}$ 의 $0.01 \mathrm{M}$ sodium phosphate buffer(pH 6.8)를 첨가하여 homogenizer(T25 Basic, Germany)로 균질한 후, $4^{\circ} \mathrm{C}$ 에서 1 시간 반응시킨 이후 $1,630 \times \mathrm{g}$ 에서 30 분간 원심분리하였다. 상등액을 분리한 후 잔사 에 $10 \mathrm{~mL}$ 의 buffer를 첨가하여 같은 방법으로 마이글로빈을 추 출하고, 획득한 상등액을 혼합하였다. 모든 상등액을 $25 \mathrm{~mL}$ 로 정용하여 Whatman No. 44 와 $0.2 \mu \mathrm{m}$ membrane filter로 여과하 였다. 여과액은 분광광도계(Uvikon 922, Germany)를 사용하여 $700 \mathrm{~nm}, 572 \mathrm{~nm}, 525 \mathrm{~nm}$ 에서 흡광도를 측정하였고, 아래의 공 식에 따라 마이오글로빈과 메트마이오글로빈의 비율을 산출하 였다( $\mathrm{A}_{\lambda}=\lambda \mathrm{nm}$ 흡광도).

마이오글로빈 함량 $(\mathrm{mg} / \mathrm{g})=\left(\mathrm{A}_{525}-\mathrm{A}_{700}\right) \times 2.303 \times$ dilution factor 메트마이오글로빈 함량 $(\%)=$

$$
\left[1.395-\left(\mathrm{A}_{572}-\mathrm{A}_{700}\right) /\left(\mathrm{A}_{525}-\mathrm{A}_{700}\right)\right] \times 100
$$

\section{관능평가}

관능평가는 훈련된 요원 15 명을 선발하여 육안으로 시료의 적색도와 명도에 대하여 9점 척도법으로 측정하였으며, 평가 점수 1점은 매우 낮음(extremely slight)으로 하고, 점수가 높을 수록 매우 강함(extremely much)으로 평가하였다.

\section{통계분석}

모든 측정 항목은 3 반복하였고, 측정 결과 값에 대하여 SAS(USA, 1999) 프로그램을 이용하여 General linear model 방법으로 분석하였다. 처리 평균 간의 비교를 위해 Duncan multiple range test로 5\% 수준에서 유의성을 검정하였다.

\section{결과 및 고찰}

\section{육색 변화}

숙성 및 가열 여부에 따른 돼지고기 표면 육색의 결과는 Table 2 와, 절단면 육색의 결과는 Table 3 과 같다. 육색 결과는 $\mathrm{L}^{*}$ 은 0 에 가까울수록 흑색에, 100 에 가까울수록 백색이며, $\mathrm{a}^{*}$ 은 +120 에 가까울수록 적색에, -120 에 가까울수록 녹색이며, $\mathrm{b} *$ 은 +120 에 가까울수록 황색에, -120 에 가까울수록 청색이다 (Girolami et al., 2013). 또한, $\mathrm{C}^{*}$ 은 0 에 가까울수록 선명하지 않으며, $\Delta \mathrm{H}$ 는 $0^{\circ}$ 에 가까울수록 적색이며, $90^{\circ}$ 에 가까울수록
녹색이며, $180^{\circ}$ 에 가까울수록 청색이며, $360^{\circ}$ 에 가까울수록 적 색이다(AMSA, 2012). 표면의 경우, 아질산염을 첨가하여 숙성 한 돼지고기 등심(NA)에서 낮은 $\mathrm{L}^{*}$ 값과 높은 $\mathrm{a}$ *값을 보였고, 이러한 결과는 아질산염에 의한 육색 안정과 액염법 염지 방법 에 의한 지질 산화의 억제 때문이라고 판단된다. 돼지고기 등 심을 가열하였을 때 $\mathrm{L}^{*}$ 값과 $\mathrm{b}$ *값이 유의적으로 증가하였는데, 이는 가열에 의하여 육색이 발현되는 마이오글로빈이 유출과 변성에 의한 것으로 사료된다. 백색도를 나타내는 $\mathrm{W}^{*}$ 값은 아 질산염을 첨가하여 숙성 $(\mathrm{NA})$ 하였을 때 감소하였고, 가열 $(\mathrm{NH})$ 하였을 때 증가하였다 $(p<0.05)$. 를 나타내는 $\mathrm{C}^{*}$ 값은 아질산염 을 첨가한 $\mathrm{N}$ 처리구(NA, NH)에서 유의적으로 높았고 $(p<0.05)$, 색의 종류를 나타내는 $\Delta \mathrm{H}$ 는 염지제를 첨가하지 않은 $\mathrm{C}$ 처리 구 $(\mathrm{CA}, \mathrm{CH})$ 에서 높게 나타났다 $(p<0.05)$. 이는 아질산염의 첨가 량이 증가할 때 $\mathrm{C}^{*}$ 값이 증가하고, $\Delta \mathrm{H}$ 값이 0 에 가까이 감소한 다는 Froehlich 등(1983)의 연구 결과처럼 본 연구 결과도 아질 산염의 첨가로 돈육의 육색이 안정되는 것으로 확인되었다.

절단면 육색의 경우, 표면 육색의 결과와 비슷한 경향을 보 였으나, 숙성한 돼지고기 등심의 절단면에서 $\mathrm{a}^{*}$ 값과 $\mathrm{C}^{*}$ 값이 표 면보다 높게 나타나는 경향을 보였다. 이는 절단면에서 지질 산화가 진행되기 전 상태이므로 선명한 선홍색을 보이는 것으 로 판단된다.

\section{잔존 아질산이온 함량 변화}

잔존 아질산이온을 측정한 결과는 Table 4에 나타내었는데, 아질산염을 첨가한 후 숙성시킨 처리구(NA)에서 가장 높은 잔존 아질산이온이 검출되었고 $(p<0.05)$, 아무 처리하지 않고 가열한 처리구 $(\mathrm{CH})$ 에서 가장 낮게 검출되었다 $(p<0.05)$. 염도 가 높을수록, 가열 온도가 높을수록 잔존 아질산이온 함량이 낮아진다는 선행 연구와 비슷한 경향으로 가열한 처리구에서 잔존 아질산이온 함량이 감소하는 경향을 보였다(Ha et al., 2015).

\section{마이오글로빈 및 메트마이오글로민 함량 변화}

마이오글로빈과 메트마이오글로빈의 함량은 Table 5 와 같다. 마이오글로빈의 함량은 아무 처리를 하지 않은 처리구(CR)에 서 가장 높았고 $(p<0.05)$, 숙성했을 때 감소하는 경향을 보였다. 메트마이오글로빈의 함량은 숙성한 처리구에서 감소했지만, 가 열한 처리구에서 증가하는 경향을 보였다. 이러한 결과는 등심 을 $5^{\circ} \mathrm{C}$ 와 $0^{\circ} \mathrm{C}$ 에서 15 일, 30 일, 45 일간 숙성하였을 때, $5^{\circ} \mathrm{C}$ 에서 숙성 기간이 증가할수록 메트마이오글로빈의 함량이 감소한다 는 Ramanathan 등(2014)의 연구 결과와 같았다. 높은 숙성 온 도와 기간이 지질 산화를 촉진시켜 메트마이오글로빈 함량이 감소하고, 육색 안정성이 떨어진다고 판단된다. 
Table 2. Effect of curing and heating pork on meat surface color

\begin{tabular}{|c|c|c|c|c|c|}
\hline \multirow{2}{*}{ |tem ${ }^{1)}$} & \multirow{2}{*}{ Treatments } & \multicolumn{4}{|c|}{ Surface color } \\
\hline & & $C^{2)}$ & $T$ & $\mathrm{~N}$ & SEM \\
\hline \multirow{4}{*}{$L^{*}$} & $\mathrm{R}^{3)}$ & $58.27^{\mathrm{Ba}}$ & $55.95^{\mathrm{Bab}}$ & $52.50^{\mathrm{Bb}}$ & 1.13 \\
\hline & A & $64.90^{\mathrm{Aba}}$ & $50.36^{\mathrm{Bb}}$ & $45.14^{\mathrm{Bb}}$ & 3.22 \\
\hline & $\mathrm{H}$ & $69.64^{\mathrm{A}}$ & $73.88^{\mathrm{A}}$ & $72.19^{A}$ & 1.08 \\
\hline & SEM & 1.93 & 3.65 & 4.19 & \\
\hline \multirow{4}{*}{$a^{*}$} & $\mathrm{R}$ & $11.76^{\mathrm{A}}$ & $12.41^{A}$ & $13.04^{\mathrm{A}}$ & 0.45 \\
\hline & A & $6.00^{\mathrm{Bab}}$ & $4.30^{\mathrm{Bb}}$ & $7.14^{\mathrm{Ba}}$ & 0.49 \\
\hline & $\mathrm{H}$ & $7.28^{\mathrm{Bb}}$ & $4.73^{\mathrm{Bb}}$ & $11.49^{\mathrm{Aa}}$ & 1.08 \\
\hline & SEM & 0.95 & 1.34 & 1.00 & \\
\hline \multirow{4}{*}{$b^{*}$} & $R$ & $4.32^{\mathrm{B}}$ & $5.25^{\mathrm{A}}$ & $4.45^{\mathrm{A}}$ & 0.29 \\
\hline & A & $0.03^{\mathrm{Ca}}$ & $-3.67^{\mathrm{Bb}}$ & $-1.70^{\mathrm{Bab}}$ & 0.70 \\
\hline & $\mathrm{H}$ & $9.07^{\mathrm{Aa}}$ & $3.37^{\mathrm{Ab}}$ & $1.13^{\mathrm{Bc}}$ & 1.21 \\
\hline & SEM & 1.34 & 1.39 & 0.99 & \\
\hline \multirow{4}{*}{$W^{*}$} & $\mathrm{R}$ & $45.30^{B}$ & $40.20^{B}$ & $39.14^{B}$ & 1.69 \\
\hline & A & $64.82^{\mathrm{Aa}}$ & $61.38^{\text {Aab }}$ & $50.25^{A b}$ & 2.73 \\
\hline & $\mathrm{H}$ & $42.44^{\mathrm{Bb}}$ & $63.76^{\mathrm{Ba}}$ & $68.81^{\mathrm{Aa}}$ & 4.19 \\
\hline & SEM & 3.68 & 3.94 & 4.68 & \\
\hline \multirow{4}{*}{$C^{*}$} & $\mathrm{R}$ & $12.53^{\mathrm{A}}$ & $13.52^{\mathrm{A}}$ & $13.80^{\mathrm{A}}$ & 0.44 \\
\hline & A & $6.11^{\mathrm{Bb}}$ & $5.68^{\mathrm{Bb}}$ & $7.62^{\mathrm{Ba}}$ & 0.36 \\
\hline & $\mathrm{H}$ & $11.68^{\mathrm{Aa}}$ & $5.84^{\mathrm{Bb}}$ & $11.55^{\mathrm{Aa}}$ & 1.06 \\
\hline & SEM & 1.07 & 1.32 & 1.01 & \\
\hline \multirow{4}{*}{$\Delta \mathrm{H}$} & $R$ & $8.18^{\mathrm{B}}$ & $8.91^{\mathrm{A}}$ & $8.41^{\mathrm{Aa}}$ & 0.20 \\
\hline & A & $3.69^{\mathrm{Ca}}$ & $-0.62^{\mathrm{Cb}}$ & $2.43^{\mathrm{Bb}}$ & 0.80 \\
\hline & $\mathrm{H}$ & $11.71^{\mathrm{Aa}}$ & $6.92 \mathrm{~B}^{\mathrm{ab}}$ & $5.84^{A b}$ & 0.94 \\
\hline & SEM & 1.19 & 1.47 & 0.97 & \\
\hline \multirow{4}{*}{$\Delta \mathrm{E}$} & $R$ & $40.22^{A b}$ & $42.77^{\text {Aab }}$ & $46.07^{\mathrm{Aa}}$ & 1.15 \\
\hline & A & $32.50^{\mathrm{Bb}}$ & $46.81^{\mathrm{Aa}}$ & $52.14^{\mathrm{Aa}}$ & 3.19 \\
\hline & $\mathrm{H}$ & $3.041^{\mathrm{Ba}}$ & $24.31^{\mathrm{Bb}}$ & $26.28^{\mathrm{Bab}}$ & 1.20 \\
\hline & SEM & 1.79 & 3.57 & 4.05 & \\
\hline
\end{tabular}

1) $L^{*}$, lightness; $a^{*}$, redness; $b^{*}$, yellowness; $W^{*}$, whiteness; $C^{*}$, chroma; $\Delta H$, Hue angle, $\Delta E$, total color difference.

2) $\mathrm{C}$, additive-free in curing solution; $\mathrm{T}$, include $\mathrm{NaCl}$ in curing solution; $\mathrm{N}$, include nitrite pickle salt $\left(\mathrm{NPS}, \mathrm{NaCl}\right.$ : $\left.\mathrm{NaNO}_{2}=99: 1\right)$ in curing solution.

3) $R$, raw meat; $A$, aging for 2 days at $5 \pm 1^{\circ} \mathrm{C} ; \mathrm{H}$, heating for 40 minutes at $90^{\circ} \mathrm{C}$ after aging.

${ }^{a-c}$ Means with different superscription within the same row differ $(\not 0.05)$.

${ }^{A-C}$ Means with different superscription within the same column differ $(\alpha 0.05)$.

\section{관능평가}

숙성 및 가열 여부에 따른 돼지고기의 관능평가를 실시한 결 과는 Table 6과 같다. 시각적으로 적색도는 아질산염을 첨가하 여 숙성한 처리구(NA)에서 유의적으로 가장 높게 나타났으며 $(p<0.05)$, 숙성 및 가열하였을 때 생고기보다 더 짙은 색을 보 였고, 아질산염을 첨가하였을 때 생고기와 숙성 및 가열한 돼
지고기 등심의 적색도가 유의적으로 높게 나타났다 $(p<0.05)$. 명도는 아질산염을 첨가하여 가열한 처리구 $(\mathrm{NH})$ 에서 유의적으 로 가장 높게 나타났으며 $(p<0.05)$, 숙성 및 가열하였을 때 생고 기보다 더 밝게 보였다 $(p<0.05)$. 이러한 결과는 조리 방법에 따 라 돼지고기 등심의 육색을 비교하였을 때 삶기와 찌기 방법에 서 가장 밝은 육색을 확인한 Yang 등(2009)의 연구 결과와 동 
Table 3. Effect of curing and heating pork on meat inner color

\begin{tabular}{|c|c|c|c|c|c|}
\hline \multirow{2}{*}{ |tem ${ }^{1)}$} & \multirow{2}{*}{ Treatments } & \multicolumn{4}{|c|}{ Inner color } \\
\hline & & $\mathrm{C}^{2)}$ & $T$ & $\mathrm{~N}$ & SEM \\
\hline \multirow{4}{*}{$L^{*}$} & $\mathrm{R}^{3)}$ & $61.59^{\mathrm{Ba}}$ & $52.17^{\mathrm{Bb}}$ & $56.13^{\mathrm{Bb}}$ & 1.55 \\
\hline & $A$ & $61.96^{\mathrm{Ba}}$ & $44.08^{\mathrm{Cc}}$ & $49.55^{\mathrm{Cb}}$ & 2.71 \\
\hline & $\mathrm{H}$ & $74.36^{A}$ & $72.67^{A}$ & $72.70^{A}$ & 0.62 \\
\hline & SEM & 2.14 & 4.32 & 3.51 & \\
\hline \multirow{4}{*}{$a^{*}$} & $R$ & $15.19^{\mathrm{Aa}}$ & $11.82^{B}$ & $14.50^{\mathrm{Cb}}$ & 0.65 \\
\hline & A & $11.22^{B}$ & $9.97^{\mathrm{AB}}$ & $11.75^{\mathrm{Bb}}$ & 0.38 \\
\hline & $\mathrm{H}$ & $9.15^{\mathrm{Cb}}$ & $9.66^{\mathrm{B}}$ & $14.84^{\mathrm{Aa}}$ & 0.93 \\
\hline & SEM & 0.92 & 0.45 & 0.60 & \\
\hline \multirow{4}{*}{$b^{*}$} & $R$ & $6.12^{\mathrm{Aa}}$ & $3.75^{\mathrm{Ab}}$ & $4.55^{\mathrm{ab}}$ & 0.45 \\
\hline & $A$ & $3.38^{\mathrm{C}}$ & $0.82^{\mathrm{B}}$ & 3.19 & 0.54 \\
\hline & $\mathrm{H}$ & $4.82^{\mathrm{B}}$ & $4.51^{\mathrm{A}}$ & 4.66 & 0.18 \\
\hline & SEM & 0.43 & 0.59 & 0.48 & \\
\hline \multirow{4}{*}{$W^{*}$} & $R$ & $43.23^{C}$ & $40.92^{B}$ & $42.49^{B}$ & 0.54 \\
\hline & $A$ & $51.82^{\mathrm{Ba}}$ & $41.61^{\mathrm{Bb}}$ & $39.98^{\mathrm{Bb}}$ & 2.06 \\
\hline & $\mathrm{H}$ & $59.89^{A}$ & $59.15^{A}$ & $58.72^{\mathrm{A}}$ & 0.77 \\
\hline & SEM & 2.42 & 3.02 & 3.14 & \\
\hline \multirow{4}{*}{$\mathrm{C}^{*}$} & $\mathrm{R}$ & $16.39^{\mathrm{Aa}}$ & $12.41^{b}$ & $15.22^{\mathrm{Aab}}$ & 0.73 \\
\hline & A & $11.73^{B}$ & 10.01 & $12.24^{\mathrm{B}}$ & 0.49 \\
\hline & $\mathrm{H}$ & $10.34^{\mathrm{Bb}}$ & $10.66^{b}$ & $15.58^{\mathrm{Aa}}$ & 0.87 \\
\hline & SEM & 0.94 & 0.49 & 0.68 & \\
\hline \multirow{4}{*}{$\Delta \mathrm{H}$} & $R$ & $9.65^{\mathrm{Aa}}$ & $7.77^{A b}$ & $8.58^{\mathrm{ab}}$ & 0.35 \\
\hline & A & $7.46^{\mathrm{Ca}}$ & $5.35^{\mathrm{Bb}}$ & $7.34^{\mathrm{a}}$ & 0.44 \\
\hline & $\mathrm{H}$ & $8.39^{B}$ & $8.16^{\mathrm{A}}$ & 8.71 & 0.14 \\
\hline & SEM & 0.34 & 0.47 & 0.38 & \\
\hline \multirow{4}{*}{$\Delta \mathrm{E}$} & $\mathrm{R}$ & $38.21^{\mathrm{Ab}}$ & $46.10^{A c}$ & $42.88^{B}$ & 1.31 \\
\hline & A & $36.67^{\mathrm{Ba}}$ & $53.47^{\mathrm{Aa}}$ & $48.58^{C}$ & 2.60 \\
\hline & $\mathrm{H}$ & $24.62^{\mathrm{Ba}}$ & $26.18^{\mathrm{Ab}}$ & $27.56^{\mathrm{C}}$ & 0.69 \\
\hline & SEM & 2.16 & 4.13 & 3.20 & \\
\hline
\end{tabular}

1) $L^{*}$, lightness; $a^{*}$, redness; $b^{*}$, yellowness; $W^{*}$, whiteness; $C^{*}$, chroma; $\Delta H$, Hue angle; $\Delta E$, total color difference.

2) $\mathrm{C}$, additive-free in curing solution; $\mathrm{T}$, include $\mathrm{NaCl}$ in curing solution; $\mathrm{N}$, include nitrite pickle salt $(\mathrm{NPS}, \mathrm{NaCl}$ : $\mathrm{NaNO}=99: 1)$ in curing solution.

3) $R$, raw meat; $A$, aging for 2 days at $5 \pm 1^{\circ} \mathrm{C} ; \mathrm{H}$, heating for 40 minutes at $90^{\circ} \mathrm{C}$ after aging.

${ }^{a-c}$ Means with different superscription within the same row differ $(\not 0.05)$.

${ }^{A-C}$ Means with different superscription within the same column differ $(\rho<0.05)$.

일하다. 따라서, 돼지고기를 삶았을 때 단백질의 변성에 의하여 마이오글로빈이 소실되며 육즙이 유리되기 때문에 숙성고기가 생고기보다 더 밟게 보였을 것이라 판단된다.

\section{결 론}

본 연구는 아질산염의 첨가 유무에 따라 숙성 및 가열에 어
떠한 영향을 미치는지 알아보고자 돼지고기 등심을 사용하여 육색, 잔존아질산이온, 마이오글로빈 및 메트마이오글로빈 함 량 등을 검사하였다. 아질산염을 첨가하여 숙성하였을 때 적색 도와 선명도에서 우수하게 평가되었지만 잔존 아질산이온 함 량이 높게 확인되었다. 이로 인하여 아질산염에 의한 육색 안 정 효과와 액염법에 의한 지질 산화 억제를 확인할 수 있었지 
Table 4. Effect of curing and heating pork on residual nitrite

\begin{tabular}{cccccc}
\hline Item & Treatments & $\mathrm{C}^{1)}$ & $\mathrm{T}$ & $\mathrm{N}$ & $\mathrm{SEM}$ \\
\hline & $\mathrm{R}^{2)}$ & $0.79^{\mathrm{A}}$ & 0.47 & $0.62^{\mathrm{B}}$ & 0.13 \\
Residual nitrite & $\mathrm{A}$ & $0.73^{\mathrm{ABb}}$ & $0.38^{\mathrm{b}}$ & $14.78^{\mathrm{Aa}}$ & 2.42 \\
$(\mathrm{ppm})$ & $\mathrm{H}$ & $0.28^{\mathrm{B}}$ & 0.49 & $0.39^{\mathrm{B}}$ & 0.05 \\
\cline { 2 - 6 } & $\mathrm{SEM}$ & 0.11 & 0.06 & 2.43 & \\
\hline
\end{tabular}

1) $\mathrm{C}$, additive-free in curing solution; $\mathrm{T}$, include $\mathrm{NaCl}$ in curing solution; $\mathrm{N}$, include nitrite pickle salt (NPS, $\mathrm{NaCl}: \mathrm{NaNO}_{2}=99: 1$ ) in curing solution.

2) $\mathrm{R}$, raw meat; $\mathrm{A}$, aging for 2 days at $5 \pm 1^{\circ} \mathrm{C} ; \mathrm{H}$, heating for 40 minutes at $90^{\circ} \mathrm{C}$ after aging.

a,b Means with different superscription within the same row differ $(p<0.05)$.

A,B Means with different superscription within the same column differ $(\alpha<0.05)$.

Table 5. Effect of curing and heating pork on myoglobin and met-myoglobin

\begin{tabular}{cccccc}
\hline Item & Treatments & $\mathrm{C}^{1)}$ & $\mathrm{T}$ & $\mathrm{N}$ & SEM \\
\hline \multirow{3}{*}{$\begin{array}{c}\text { Myoglobin } \\
\text { (mg/g) }\end{array}$} & $\mathrm{R}^{2)}$ & $3.06^{\mathrm{A}}$ & $0.00^{\mathrm{B}}$ & 2.38 & 0.79 \\
& $\mathrm{~A}$ & $0.00^{\mathrm{B}}$ & $0.00^{\mathrm{B}}$ & 0.52 & 0.12 \\
\cline { 2 - 5 } & $\mathrm{H}$ & $0.70 \mathrm{~A}^{\mathrm{B}}$ & $1.00^{\mathrm{A}}$ & 0.73 & 0.12 \\
\hline \multirow{2}{*}{$\begin{array}{c}\text { Met-myoglobin } \\
\text { (\%) }\end{array}$} & $\mathrm{SEM}$ & 0.61 & 0.19 & 0.58 & \\
& $\mathrm{R}$ & $66.45^{\mathrm{Ba}}$ & $0.00^{\mathrm{Bb}}$ & $66.65^{\mathrm{a}}$ & 11.15 \\
& $\mathrm{~A}$ & $0.00^{\mathrm{C}}$ & $0.00^{\mathrm{B}}$ & 49.86 & 10.99 \\
& $\mathrm{H}$ & $75.76^{\mathrm{A}}$ & $75.70^{\mathrm{A}}$ & 71.19 & 1.25 \\
\hline
\end{tabular}

1) $\mathrm{C}$, additive-free in curing solution; $\mathrm{T}$, include $\mathrm{NaCl}$ in curing solution; $\mathrm{N}$, include nitrite pickle salt (NPS, $\mathrm{NaCl}: \mathrm{NaNO}_{2}=99: 1$ ) in curing solution.

2) $\mathrm{R}$, raw meat; $\mathrm{A}$, aging for 2 days at $5 \pm 1^{\circ} \mathrm{C}$; $\mathrm{H}$, heating for 40 minutes at $90^{\circ} \mathrm{C}$ after aging.

a,b Means with different superscription within the same row differ $(\not<0.05)$.

${ }^{A-C}$ Means with different superscription within the same column differ ( $\left.\propto<0.05\right)$.

Table 6. Effect of curing and heating pork on sensory evaluation

\begin{tabular}{|c|c|c|c|c|c|}
\hline Item & Treatments & $C^{1)}$ & $T$ & $\mathrm{~N}$ & SEM \\
\hline \multirow{4}{*}{ Redness } & $R^{2)}$ & $6.17^{\mathrm{Ab}}$ & $5.67^{\mathrm{Cc}}$ & $6.83^{\mathrm{Ba}}$ & 0.10 \\
\hline & A & $4.67^{\mathrm{Bc}}$ & $6.50^{\mathrm{Ab}}$ & $7.42^{\mathrm{Aa}}$ & 0.18 \\
\hline & $\mathrm{H}$ & $6.42^{\mathrm{Ab}}$ & $6.10^{\mathrm{Bc}}$ & $7.29^{\mathrm{Aa}}$ & 0.09 \\
\hline & SEM & 0.13 & 0.08 & 0.08 & \\
\hline \multirow{4}{*}{ Lightness } & $R$ & $5.67^{B}$ & $5.67^{B}$ & $5.67^{C}$ & 0.06 \\
\hline & A & $6.50^{\mathrm{A}}$ & $6.13^{\mathrm{A}}$ & $6.42^{\mathrm{B}}$ & 0.09 \\
\hline & $\mathrm{H}$ & $6.17^{\mathrm{Ab}}$ & $6.46^{\mathrm{Aab}}$ & $6.79^{\mathrm{Aa}}$ & 0.08 \\
\hline & SEM & 0.10 & 0.08 & 0.09 & \\
\hline
\end{tabular}

1) $\mathrm{C}$, additive-free in curing solution; $\mathrm{T}$, include $\mathrm{NaCl}$ in curing solution; $\mathrm{N}$, include nitrite pickle salt (NPS, $\mathrm{NaCl}: \mathrm{NaNO}_{2}=99: 1$ ) in curing solution.

2) $R$, raw meat; $A$, aging for 2 days at $5 \pm 1^{\circ} \mathrm{C} ; \mathrm{H}$, heating for 40 minutes at $90^{\circ} \mathrm{C}$ after aging.

a,b Means with different superscription within the same row differ $(\propto 0.05)$.

$A, B$ Means with different superscription within the same column differ ( $p<0.05)$. 
만, 잔존 아질산이온의 함량이 소비자에게 부정적인 영향을 미 칠 것으로 사료된다. 아질산염을 첨가하여 가열하였을 때 적색 도과 선명도에서 우수하게 평가되었으며, 잔존 아질산이온 함 량이 감소하였음을 확인하였다. 이러한 결과로 아질산염에 의 하여 육색이 보존되었음을 확인하였고, 가열함에 따라 단백질 변성에 의한 육즙이 유리되는 동시에 아질산이온의 삼출이 발 생하였을 것이라고 판단된다. 따라서 소비자의 돈육 선호도에 영향을 미치는 가장 중요한 요소인 육색에 있어서 아질산염의 첨가로 인하여 안정된 발색을 확인하였고, 가열 시 잔존 아질 산이온의 함량이 감소하였기 때문에 아질산염의 섭취를 줄이 기 위하여 적절한 가열이 필요하다고 판단된다.

\section{Conflicts of Interest}

The authors declare no potential conflict of interest.

\section{Acknowledgments}

This work was supported by the RAIC at Gyeongnam National University of Science and Technology and by Korea Institute of Planning and Evaluation for Technology in Food, Agriculture, Forestry and Fisheries (IPET) through High Value-added Food Technology Development Program, funded by Ministry of Agriculture, Food and Rural Affairs (MAFRA, 316064-02-1-HD020).

\section{Ethics Approval}

This article does not require IRB/IACUC approval because there are no human and animal participants.

\section{Author Contributions}

Conceptualization: Lee SY

Data curation: Kang HJ

Formal analysis: Kang HJ, Lee SY

Validation: Kang HJ, Jin SK, Lee SY

Investigation: Kang $\mathrm{JH}$

Writing-original draft: Kang HJ

Writing-review\&editing: Kang HJ, Jin SK, Lee SY

\section{Author Information}

Hea Jin Kang (Master's student, Chung-Ang University) https://orcid.org/0000-0001-6765-3434

Seung Yun Lee (Postdoctoral Fellow, Chung-Ang University) https://orcid.org/0000-0002-8861-6517

Sang Keun Jin (Professor, Gyeongnam National University of
Science and Technology)

https://orcid.org/0000-0002-8983-5607

\section{References}

American Meat Science Association. 2012. Meat color measurement guidelines. American Meat Sci Association: Champaign, IL, USA.

Chen HH. 2002. Decoloration and gel-forming ability of horse mackerel mince by air-flotation washing. J Food Sci 67: 2970-2975.

Cho SH, Jung SA, Song EJ, Lee SY, Kim KBWR, Park JG, Park SM, Ahn DH. 2006. Effect of improvement of storage properties and reducing of sodium nitrate by Glycyrrhiza uralensis and Curcula longa in pork sausage. J Korean Soc Food Sci Nutr 35:997-1004.

Claus JR. 2007. Color changes in cooked beef. National Cattlemen's Beef Association, Centennial, CO, USA.

Faustman C, Sun Q, Mancini R, Suman SP. 2010. Myoglobin and lipid oxidation interactions: Mechanistic bases and control. Meat Sci 86:86-94.

Froehlich DA, Gullett EA, Usborne WR. 1983. Effect of nitrite and salt on the color, flavor and overall acceptability of ham. J Food Sci 48:152-154.

Girolami A, Napolitano F, Faraone D, Braghieri A. 2013. Measurement of meat color using a computer vision system. Meat sci 93:111-118.

Greene BE, Hsin IM, Zipser MYW. 1971. Retardation of oxidative color changes in raw ground beef. J Food Sci 36:940-942.

Ha SR, Choi JS, Jin SK. 2015. The physicochemical properties of pork sausages with red beet powder. J Life Sci 25: 896-902.

Han BK, Choi HJ, Park YS. 2012. Antimicrobial and antioxidative activities of phytic acid in meats. Food Eng Prog 16:145-150.

Jeong HJ, Lee HC, Chin KB. 2010. Effect of red beet on quality and color stability of low-fat sausages during refrigerated storage. Korean J Food Sci Anim Resour 30: 1014-1023.

Kim GS, Choi SH. 2007. Changes in residual nitrite, TBARS and color of meat products during storage. Korean J Food Sci Anim Resour 27:299-307.

Kim JD, Lee OH, Lee JS, Jung HY, Kim B, Park KY. 2014. Safety effects against nitrite and nitrosamine as well as 
anti-mutagenic potentials of kale and Angelica keiskei vegetable juices. J Korean Soc Food Sci Nutr 43:12071216.

Ministry of Food and Drug Safety [MFDS]. 2020. Food Code. Available from: http://www.foodsafetykorea.go.kr/foodcode/ 01_03.jsp?idx=37. Accessed at Agu 27, 2020.

Park WY, Kim YJ. 2009. Effect of garlic and onion juice addition on the lipid oxidation, total plate counts and residual nitrite contents of emulsified sausage during cold storage. Korean J Food Sci Anim Resour 29:612-618.
Ramanathan R, Mancini RA, Van Buiten C. 2014. Effects of aging temperature and time on beef longissimus color intensity and stability. Meat Sci 96:491.

Yang JB, Ko MS, Moon YH. 2009. Physicochemical changes in pork loins affected by different cooking methods. Korean J Food Preserv 16:534-540.

(c) Copyright. Korean Society for Food Science of Animal Resources. Date Received Jul. 27, 2020 Date Revised Aug. 31, 2020 Date Accepted Sep. 1, 2020 